\title{
EVALUATION OF THE IMPACTS OF LACK OFGEOINFORMATION DATA IN CRISIS MANAGEMENT DURING THE 2018 KUWAIT FLOOD
}

\author{
N. Alghais ${ }^{1 *}$ \\ ${ }^{1}$ Kuwait University, College of Social Sciences, Geography Department, Kuwait - dr.ghais@gmail.com
}

KEY WORDS: Geoinformatics, GIS, Remote sensing, Crisis Management, Floods, Kuwait

\begin{abstract}
:
The State of Kuwait faced a catastrophic flood on the $9^{\text {th }}$ of November 2018 due to extraordinary rainfall of around $111 \mathrm{~mm}$ in less than 6 hours. Such an extreme flood event has not been observed in Kuwait for the last 50 years. In this research, we attempt to understand the crisis management in Kuwait from a Geoinformatics perspective. Remote sensing and GIS were used to investigate the flood impacts and response efficiency in Kuwait city, Fahaheel city and Sabah Al-Ahmad city. A comparison was carried out based on the availability of Geoinformation data and tools, the response time for each city, and the number of recorded incidents. It was found that the response to the flood event was overall lacking, mainly due to the absence of accurate geoinformation data and the lack of real-time monitoring of the drainage network. In addition, the absence of a centralized crisis management authority in Kuwait that could coordinate the various related bodies involved in flood response aggravated the issue.
\end{abstract}

\section{INTRODUCTION}

The country of Kuwait has an arid climate due to its desert location and it very seldom experiences heavy rainfall. As a result, when heavy rains do occur they often cause flash floods that can be very destructive for a country that lacks the infrastructure to deal with them on a regular basis. On the $4^{\text {th }}$ and $5^{\text {th }}$ of November 2018 , such torrential rains and flash floods caused major disruptions and damages across Kuwait. The rainfall was accompanied by thunderstorms and gusts reaching up to $115 \mathrm{~km} / \mathrm{h}$. A few days later, on the $9^{\text {th }}$ $10^{\text {th }}$ and $14^{\text {th }}-15^{\text {th }}$ of the same month, further serious flooding was recorded. Statistics from the National Meteorological Department show that within 24 hours on the 9th of November alone, Kuwait received $111 \mathrm{~mm}$ of rain in less than 6 hours (Floodlist News in Asia, 2018), which was more than 5 times the rainfall usually received in the whole month of November (Aljazeera, 2018). The results of these floods included damage to major roads and bridges, private property and significant congestion during the month of November. Several newly built residential districts had to be evacuated by the Kuwait police and National Guard. Many vehicles were swept away and destroyed by strong water currents and many roads and tunnels were filled with water and clay (The New Arab, 2018). One person lost their life during the flash floods and an unspecified number of people were injured (estimated at more than 400) in traffic accidents (Arab News, 2018). Schools, universities and other government institutions, including the state-owned Kuwait Petroleum Corporation, had to be closed during the storms, while all flights had to be suspended on the $14^{\text {th }}$ November as parts of Kuwait's airport were flooded. The New Arab
(2018) reports that the Kuwait flood damages are estimated at over $\$ 300$ million.

All these damages and disruptions caused the resignations of the Public Works Minister and the presidents of the Public Authority of Roads and Transportation. Before these extreme phenomena unfolded, Kuwait's Meteorological Department issued severe weather warnings; however, the government was not able to prevent the flooding due to the absence of a centralized crisis management authority in Kuwait. The problem was compounded by the absence of accurate geo-information data and the lack of real-time monitoring of the drainage network. Given the acute flood problems in Kuwait in 2018, the local authorities should give special attention to use of GIS models with low cost and simple data requirements that are able to provide essential inputs towards comprehensive management of floods.

\section{BACKGROUND}

A critical step in managing the risks and impacts of heavy rains and floods in such situations is to recognize regions that have higher hazard potential. Setting up a hazard map can be achieved via GIS and remote sensing data. The majority of flood risk management studies refer to these hazard maps in situations where river flood risk are common. Kuwait doesn't have rivers, however applications of remote sensing and GIS in other contexts can help understand the ways that these techniques could have been helpful in Kuwait's situation. 
Flood depth is regarded as the most significant indicator of the intensity of the flood hazard (Isma'il \& Saanyol, 2011). Flood risk maps are developed based on the evaluated depth of inundation. The estimation is largely done from different hydrological and remotely sensed data. To distinguish flood depths, it is essential to characterize the phenomenon of flooding into two classes, in particular, the 'non-source flood' and 'source flood'. 'Non-source flood' is an immersion resulting from evenly distributed rainstorms over a large area, while 'source flood' entails an immersion caused by overbank flow, transcendently affecting areas bordering the river channel (Uddin et al., 2013). These two fundamental attributes of overland flow have significant implications for formulating GIS models for flood management. On account of 'non-source' floods, all the raster cells or vector points with an elevation below the water level are regarded as 'inundated'. On the other hand, for source floods there is need to simulate the path of overbank flow from the primary channel to the adjacent flood plain in order to precisely gauge the flood affected area.

The idea of topographical convergence or wetness index may be utilized to estimate the depth of inundation (Musaoglu et al., 2002). The concept of wetness index works on the premise that the collection of water in a specific cell of a raster depends on the upslope feeding water to that specific cell. However, the main issue of utilizing this index is that when the topographical slope tends to zero, the wetness index progresses toward becoming undefined. Hence, this index is not helpful when modelling extremely flat flood plains. Isma'il \& Saanyol (2013) utilized an alternative model for simulating 'source flooding'. Their model presumes that the potential for any site to be inundated depends on the differences in elevation between that site and the stream at its closest hydrological link. This highlights the importance of topographic maps that are used in the present study.

Possibly the most innovative and cost effective approach to flood management involves the assessment of flood depth from NOAA AVHRR imageries according to the tonal contrast of flood water (Deckers et al., 2009). In this practice, the flood affected zone is divided into various flood depth zones utilizing supervised classification. In order to precisely recognize the training sets, the AVHRR information is superimposed over a Digital Elevation Model (DEM). Eventually, flood risk is assessed by ascertaining a weighted score for each land use, physiographic and geologic division. This procedure allocates greater weight to the classes of more profound flood depths in an exponential way. This ensures that flood areas having higher depth of inundation will be marked with a high hazard flag. The premise is based on the fact that after a certain depth, the flood water turns out to be severely damaging, and distinguishing these depths is vital for mapping hazard zones. These critical depths fluctuate from one area to the other contingent upon the local topography, settlement patterns, building materials, etc.

Geospatial data has also been useful in integrating population density and hazard positioning and in creating land development priority maps (Sanyal \& Lu, 2004). This strategy is dependent upon the ability of the analyst who decides the training sets for each locale for various depths of inundation. The process of deciding the training sets is often hampered by forest cover and varying sediment load of the flood water, both of which may change the natural relationship of the depth of water and its appearance on hazard maps. A principal limitation of this method is that AVHRR imagery is in most cases too coarse for utilization in analysing local floods, as cloud free pictures are uncommon, particularly in the monsoon season. Other geospatial data types used in developing flood hazard maps include land use, hydraulic characteristics of flows, demographics and land ownership (Sanyal \& Lu, 2004).

Despite the growing applications of GIS and remote sensing in managing flood risks, flood hazard maps generated from low to moderate resolution imageries are not always a good fit for developed nations, as they can rarely pinpoint practical improvements to the existing advanced flood safety frameworks. However, these maps are very valuable for countries without a well-developed flooding management system. Unfortunately, in Kuwait flood hazard maps are almost never developed or utilised. The current study proposes the generation of flood hazard maps through GIS and remote sensing for Kuwait and hypothesises that they could be utilized meaningfully in disaster preparedness and management to formulate strategies for combating flood risks and crises like the 2018 case. The proposed hazard maps should have a decent enhanced visualization so that the end user has an overview of the whole situation at a glance (i.e. government authorities) in real time.

To that end this paper research main aim is to demonstrate the usefulness of flood hazard maps by comparing their outputs with real data from the 2018 floods. In doing so, the present study identifies the types of available geoinformation data that can be used to model the flood crisis in Kuwait and compares the model outputs to the impacts of the 2018 floods in respect to the number of recorded accidents, emergency response times and percentages of blocked streets. The findings from the model's results are evaluated in terms of their applicability in future crisis management scenarios from the government authorities.

The methodology of the present study involves using GIS and remote sensing to simulate the 2018 floods for 3 cities in Kuwait and generating maps with the model predictions. The following cities were chosen as case studies for the simulations: Kuwait City (unflooded during the 2018 floods), Fahaheel City and Sabah Al-Ahmad City (both flooded during the 2018 floods).

The selection of these cities was based on the author's knowledge and in order to include one unflooded city for control and of the most negatively affected cities in the flood crisis according to the local news and social media. The 3 case study cities can be seen in Figure 1 . 


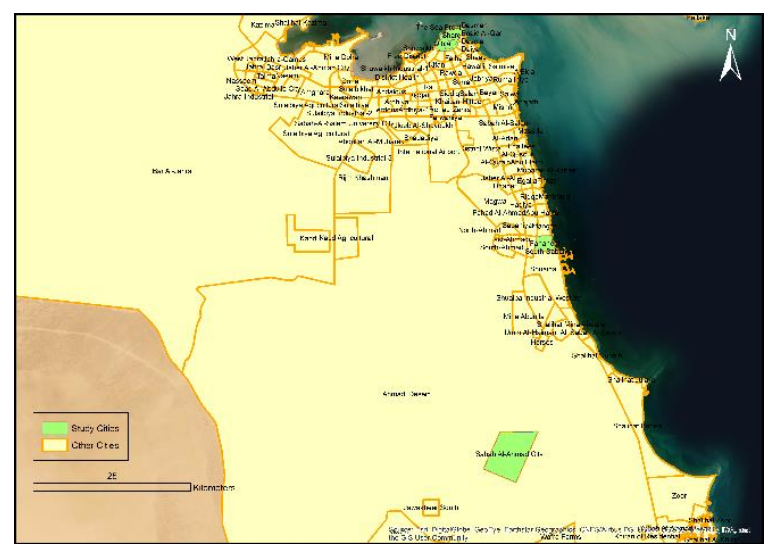

Figure 1 . The 3 case study city locations marked in green

\section{METHODOLOGY}

\subsection{Data collection}

The following types of data were collected for completing the present study:

- $\quad$ GIS ready data from the company Vision Vision International in Kuwait (Vision Vision International, 2019), including ESRI satellite images for Kuwait (ArcMap) and contour map (with interval=5m) as shown in Figure 2.

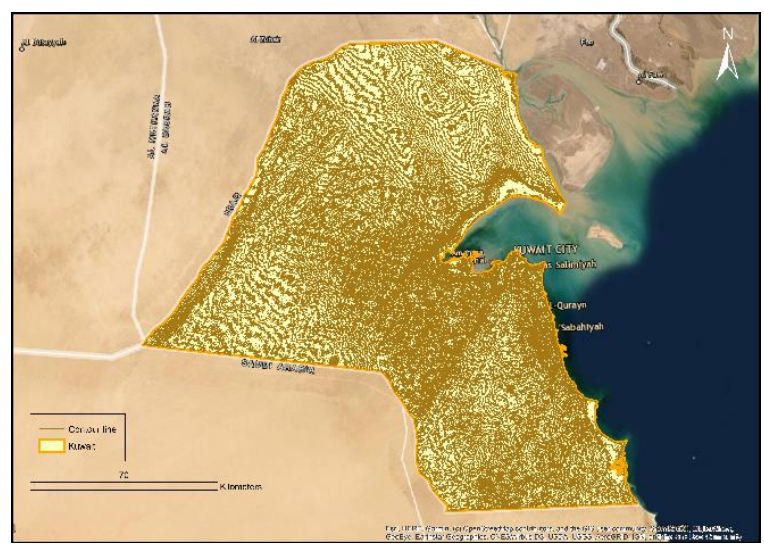

Figure 2. Kuwait contour map

- Locations of facilities, such as hospitals, police stations and fire stations, as shown in Figure 3.

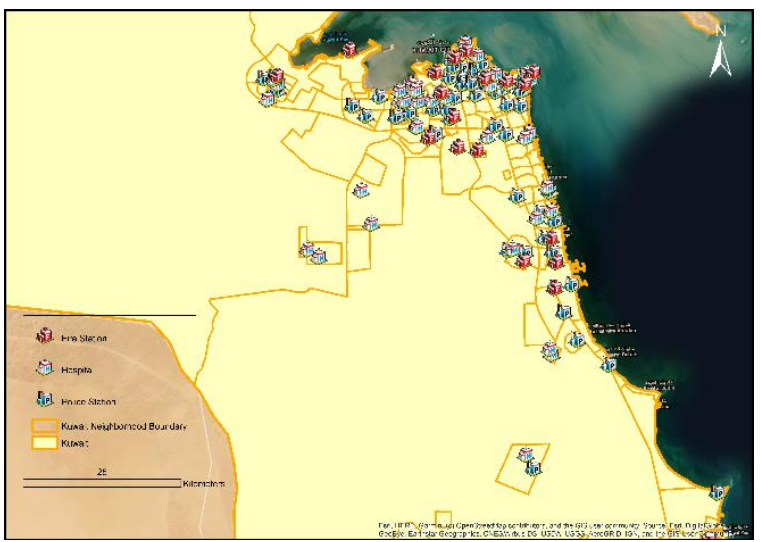

Figure 3. Emergency facilities locations

- Road network maps with the speed limits and street lengths.

- Administrative divisions of neighbourhoods, districts and cities in Kuwait.

- Traffic accident data with geo-coordinates and street name in the 3 case study cities from the Interior Ministry- Information Centre, shown in Table 3.

- Rain water manholes from the Public Works Ministry.

- Major streets that were flooded during the November 2018 floods collected from the Public Authority of Roads and Transportation.

\subsection{Data preparation and disaggregation}

The proposed system uses Digital Elevation Model (DEM) to draw the drainage network and concepts of network analysis for calculating emergency responses. The initial step in preparing the data was to transfer the contour map data into a Digital Elevation (DE) raster map by using the "Topo to raster" tool in ArcMap. The resolution of the ratster map was chosen to be $100 \times 100 \mathrm{~m}$, due to hardware constraints. The DE raster map can be seen in Figure 4. 


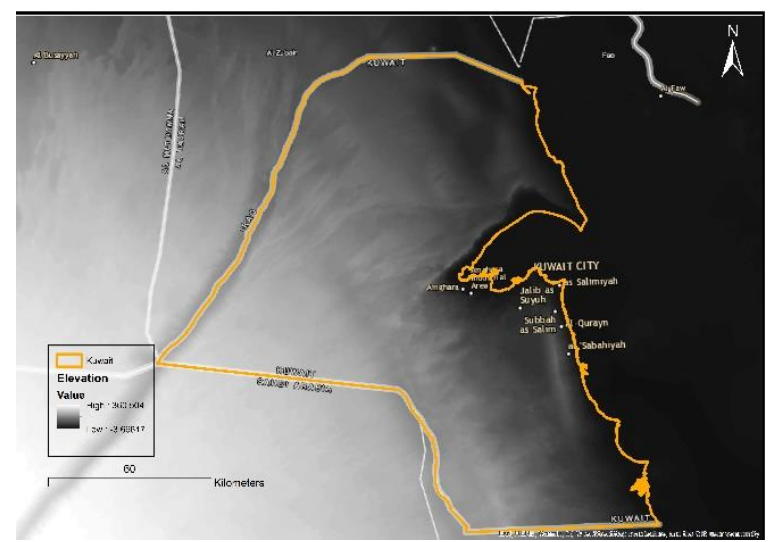

Figure 4. Kuwait DEM raster map

The next step involved developing the drainage network with the Filling tool of ArcMap. The accident data were entered manually in attribute tables for the cities layer. The maps generated after the accident data has been integrated into each of the three case study city maps can be seen in Figures 5, 6 and 7.

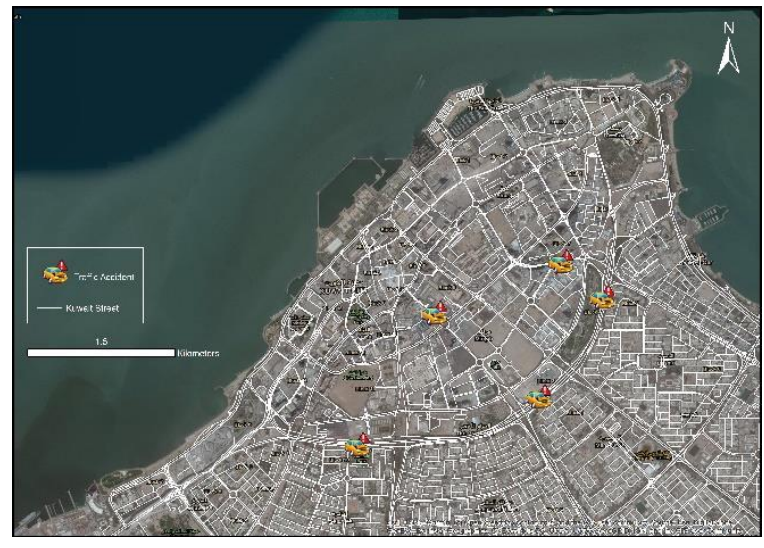

Figure 5. Kuwait city accident locations

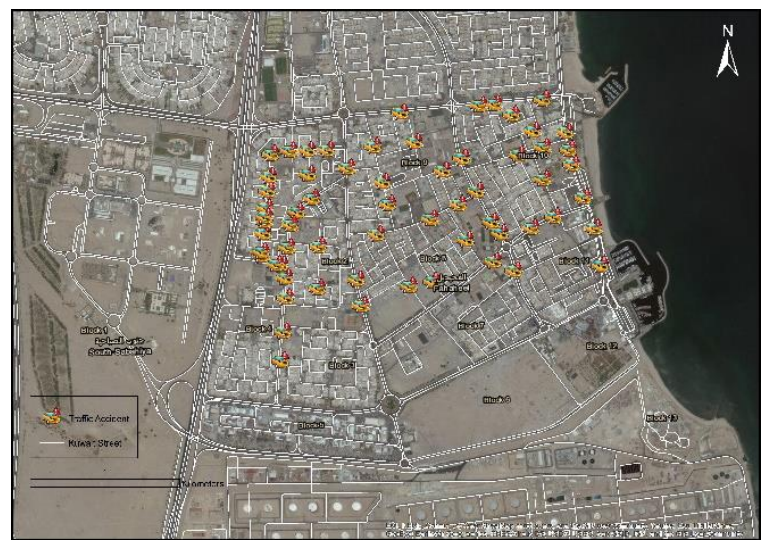

Figure 6. Fahaheel city accident locations

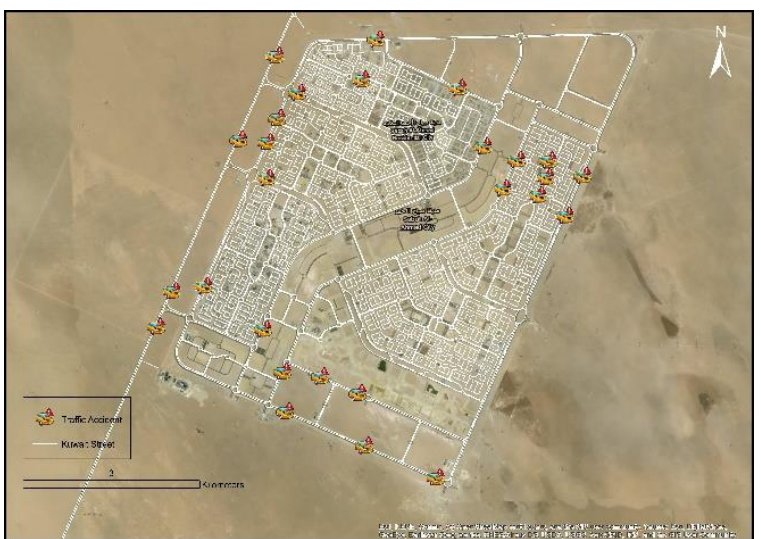

Figure 7. Sabah Al-Ahmad city accident locations

In a similar fashion, the major flooded streets from 2018 were imported in an attribute table for the street network layer. The maps produced after this step can be seen in Figures 14 and 15.

\subsection{Model design and outputs}

The design of the model can be outlined in the flowchart seen in Figure 8.

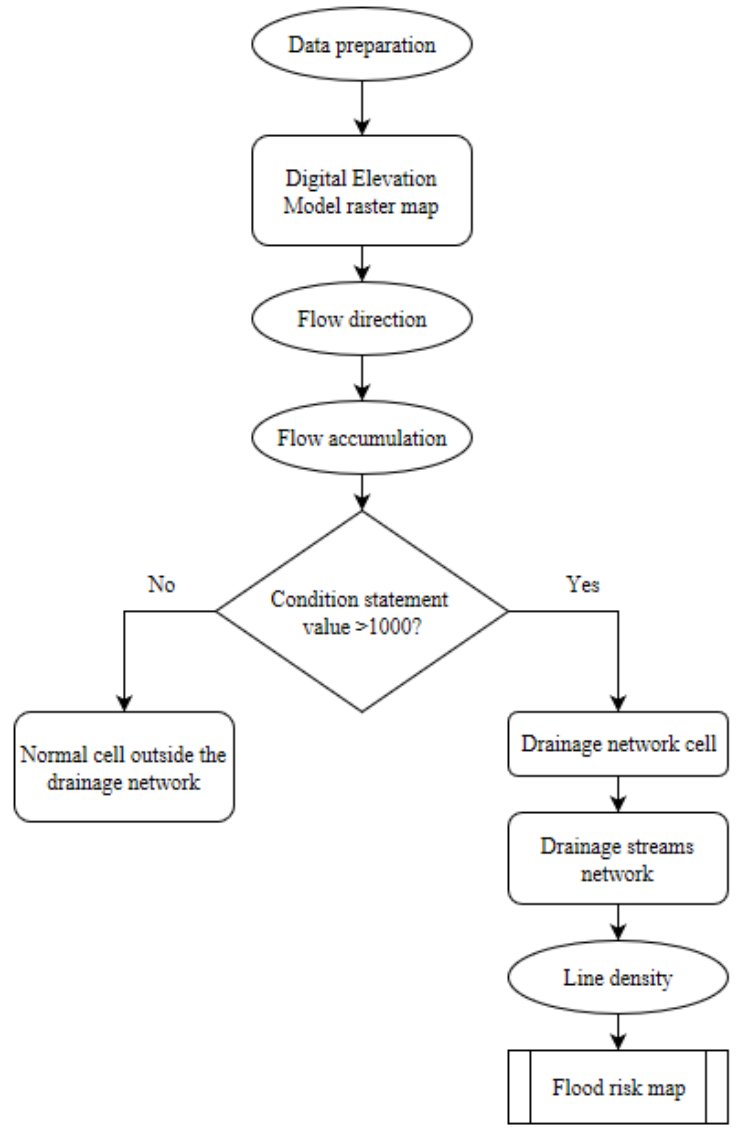

Figure 8 . The flood model design flowchart 
The Flow Direction tool provides a specific direction for each cell in the DE raster map that shows the water (flood) direction. The outcome map with the Flow Direction outputs is shown in Figure 9.

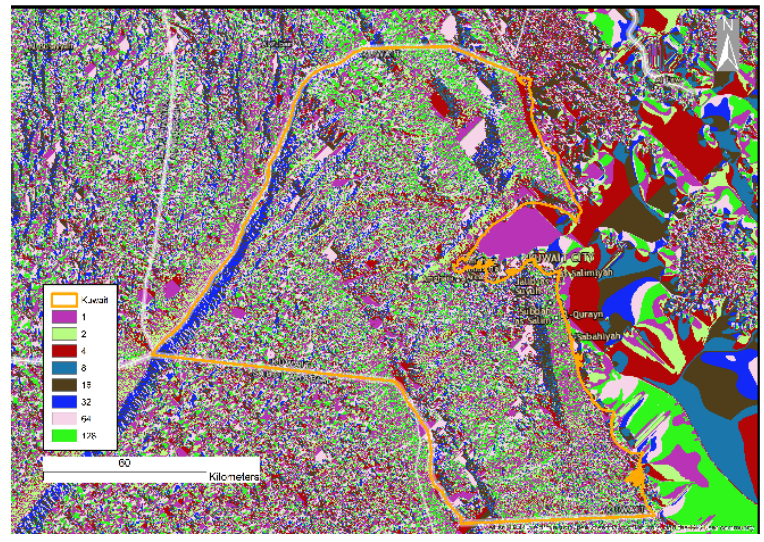

Figure 9. Flow Direction map

The Flow Accumulation tool creates a new raster map that assigns weights for each cell based on the Flow Direction raster map. For example a weight of 3 means that three surrounding cells feed water into the selected cell. High weights mean high water flood direction and hence high risk of flooding. The outcome map from the Flow Accumulation step can be seen in Figure 10.

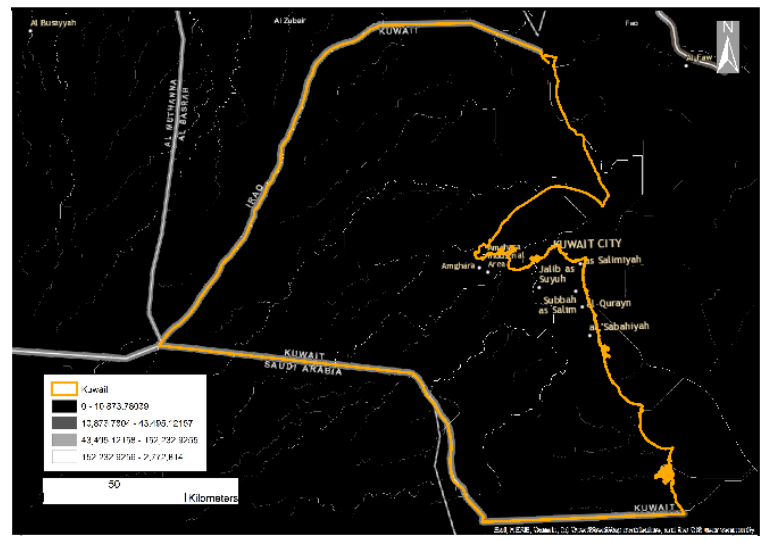

Figure 10. Flow Accumulation map

The next step is developing the drainage network under the following condition: if the cell weight was greater than 1,000 the selected cell is treated as a drainage network cell, else it is a normal cell outside the drainage network. The map showing the cell classifications can be seen in Figure 11.

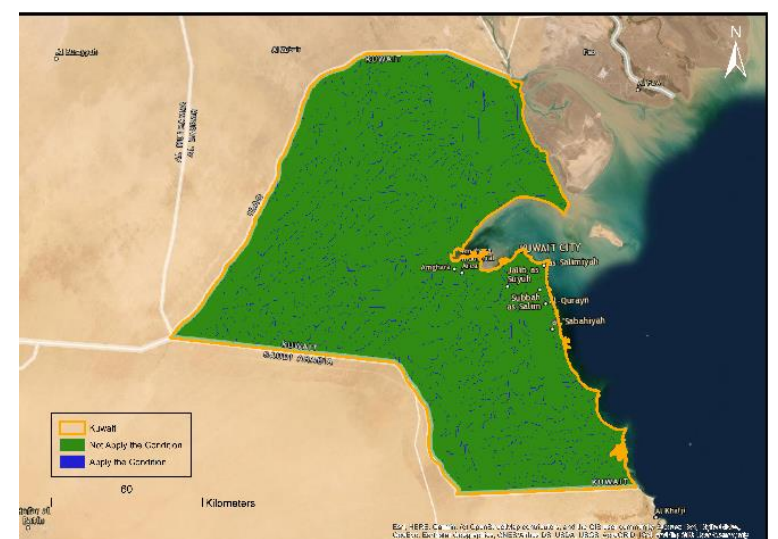

Figure 11. Drainage stream network in raster

The Stream to feature tool converts the raster map with the drainage streams network into vector format (lines). The line density is then calculated and the outcome map is shown in Figure 12.

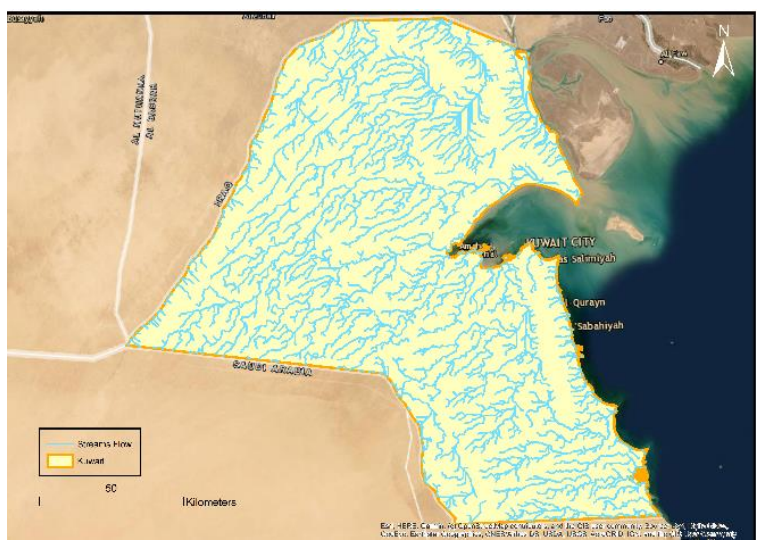

Figure 12. Drainage stream network in vector

Finally, the flood risk map is developed with the areas being classified as one of the three classes, according to the number of flood streams present in them.

1. Low risk: no flood stream.

2. Medium risk: at least 1 stream

3. High risk: 2 or more stream adjacent to each other

The flood risk map can be seen in Figure 13. 


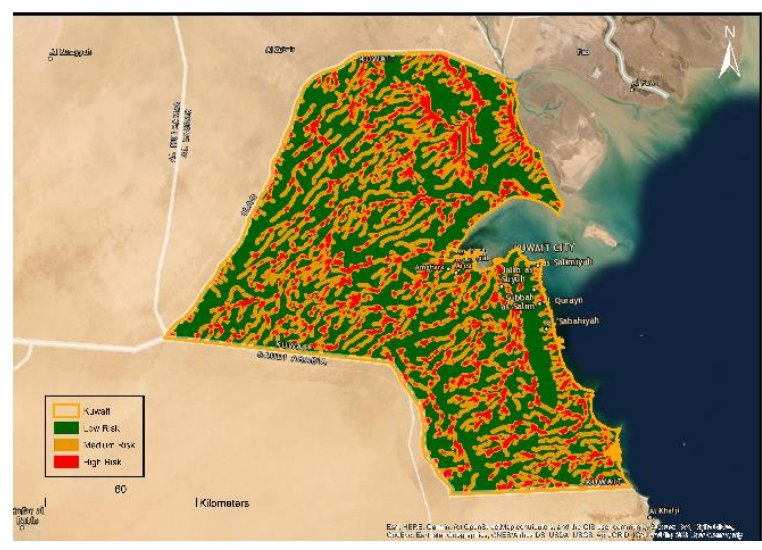

Figure 13. Kuwait flood risk map

\subsection{Comparison results of model outputs and 2018 floods data}

The flood risk map can be compared visually the map containing collected real data from 2018. After overlapping the two map layers it was confirmed that all the flooded streets from the 2018 incident matched high risk areas from the flood risk map. This can be seen in Figures 14 and 15 for Fahaheel and Sabah Al-Amad cities respectively.

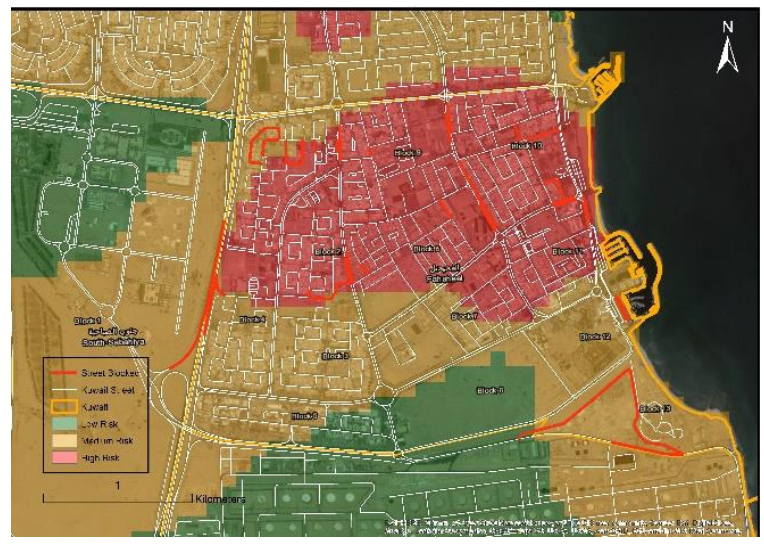

Figure 14. Fahaheel flooded street locations overlayed on the risk map

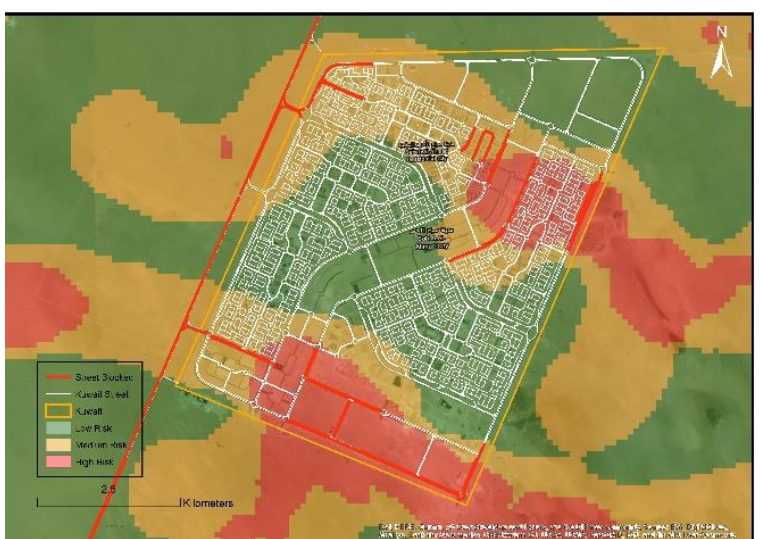

Figure 15. Sabah Al- Ahmad city flooded street locations overlayed on the risk map

The data has shown that Kuwait City was the city with the least flood problems, which matches the model predictions as it was classified as Low risk area. Fahaheel and Sabah AlAhmad cities on the other hand were classified as high risk in the model and were indeed faced with major flood issues. Besides the lower slope in both cities, old and insufficient drainage infrastructure aggravated the floods.

Network analysis was then used in order to calculate the delay in emergency responses. Initially, the fastest path for emergency vehicles between the street with the highest number of accidents and the nearest facility (fire station, hospital or police station) was determined with the help of the Network Analyst extension in ArcMap. This was achieved by minimising the time under constraints such as the road width and speed limits. The result times can be seen in Table 1 under normal conditions (no flooding).

\begin{tabular}{|l|l|l|}
\hline Facility & City & $\begin{array}{l}\text { Response } \\
\text { time (min) }\end{array}$ \\
\hline Alsalam International Hospital & KC & 6 \\
\hline Alamiri Hospital & KC & 8 \\
\hline Helaly Fire Station & KC & 6 \\
\hline $\begin{array}{l}\text { General Administration of Fire } \\
\text { Extinguishing }\end{array}$ & KC & 10 \\
\hline Alsalheyah Police Station & KC & 12 \\
\hline Al Ahmadi Hospital & FC & 14 \\
\hline Fahaheel Fire Station & FC & 6 \\
\hline Fahaheel Police Station & FC & 12 \\
\hline Sabah Al-Ahmad Hospital & SC & 5 \\
\hline Sabah Al-Ahmad Fire Station & SC & 70 \\
\hline Fire Station Wafra & SC & 22 \\
\hline Sabah Al-Ahmad Police Station & SC & 9 \\
\hline
\end{tabular}

Table 1: Response times from nearest emergency facility to the roads with the highest number of accidents under normal 
conditions; KC: Kuwait City, FC: Fahaheel City, SC: Sabah Al- Ahmad City

The path resulting into the fastest route was recalculated with the Network Analyst extension again, this time assuming that parts of the motor network were flooded according to the prior results and these roads could not be used by the emergency vehicles. The outcomes can be seen in Table 2 and Figure 16. The delay times are in comparison to the times shown in Table 1 .

\begin{tabular}{|l|l|l|}
\hline Facility & City & $\begin{array}{l}\text { Delay time } \\
(\mathrm{min})\end{array}$ \\
\hline Alsalam International Hospital & KC & 0 \\
\hline Alamiri Hospital & KC & 0 \\
\hline Helaly Fire Station & KC & 0 \\
\hline $\begin{array}{l}\text { General Administration of Fire } \\
\text { Extinguishing }\end{array}$ & KC & 0 \\
\hline Alsalheyah Police Station & KC & 0 \\
\hline Al Ahmadi Hospital & FC & 8 \\
\hline Fahaheel Fire Station & FC & 4 \\
\hline Fahaheel Police Station & FC & 5 \\
\hline Sabah Al-Ahmad Hospital & SC & 3 \\
\hline Sabah Al-Ahmad Fire Station & SC & 15 \\
\hline Fire Station Wafra & SC & 76 \\
\hline Sabah Al-Ahmad Police Station & SC & 11 \\
\hline
\end{tabular}

Table 2: Response times from nearest emergency facility to the roads with the highest number of accidents under flood conditions; KC: Kuwait City, FC: Fahaheel City, SC: Sabah Al- Ahmad City

Additionally, the percentage of blocked streets was calculated as the ratio of flooded streets from the 2018 data over the total streets. A comparison of the percentage of blocked streets and recorded accidents in each city can be seen in Table 3.

\begin{tabular}{|l|l|l|l|}
\hline City & $\begin{array}{l}\text { Number of } \\
\text { recorded } \\
\text { accidents }\end{array}$ & $\begin{array}{l}\text { Blocked } \\
\text { streets number }\end{array}$ & $\begin{array}{l}\text { Blocked streets } \\
\text { percentage }\end{array}$ \\
\hline KC & 5 & 0 & $0 \%$ \\
\hline FC & 62 & 35 & $17 \%$ \\
\hline SC & 27 & 25 & $23 \%$ \\
\hline
\end{tabular}

Table 3: Comparison of accidents and blocked streets during the floods of 2018 in each city

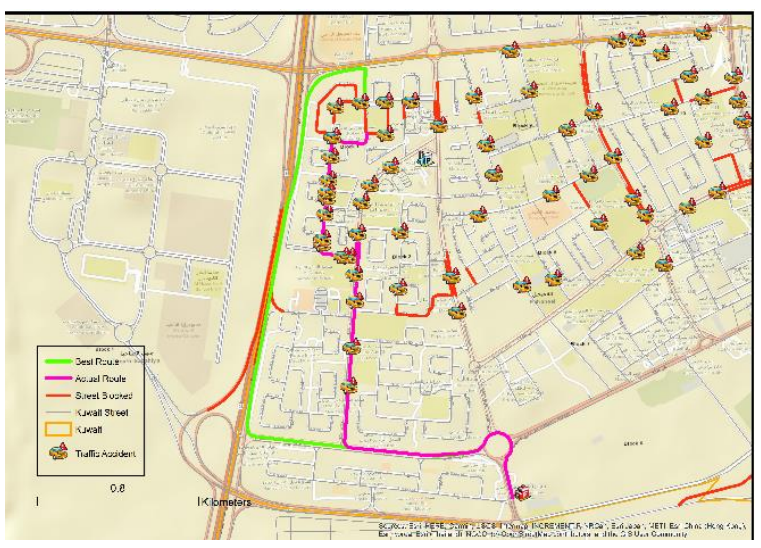

Figure 16. Network Analyst outcome map for Fahaheel

Using the results from the comparisons between real and model output data, a final risk map was developed that can be used for future crisis management by the responsible government authorities in Kuwait and is seen in Figure 13.

\section{CONCLUSIONS}

This research found that geospatial data can be used in GIS for flood management after preparation and disaggregation. The use of GIS (ArcMap tools) can help with modelling the appearance of floods as it demonstrated a high accuracy in matching the flood risk zones with the actual flooded streets from the incidents of November 2018 in Kuwait. It was also found that the use of GIS is helpful for managing emergency situations, especially if there is an official supervisory government authority or body to coordinate any response vehicles to avoid flooded streets. Fahaheel City was the city most affected by floods, as evidenced by the highest number of recorded accidents and high delays in emergency response times. Sabah Al-Ahmad was also detrimentally affected, as it had the highest percentage of blocked streets and delays in response times.

The findings of the present study shall be taken under consideration in future planning from the Kuwait government. The application of GIS and remote sensing in flood risk analysis and management is convincingly costeffective and efficient in helping citizens in distress. This type of very high resolution modelling and response methodologies are ideal for countries without established flood management systems such as Kuwait.

\section{ACKNOWLEDGEMENTS (OPTIONAL)}

I would like to Thank Vision International for providing the necessary GIS data and Eng. Ahmed Mokhtr Ali for his help.

\section{REFERENCES}

Aljazeera, 2018. Kuwait: Flights resume after flooding disrupted air traffic. Retrieved from https://www.aljazeera.com/news/2018/11/kuwait-flights- 
resume-flooding-disrupted-airtraffic181115113729351.html

Arab News, 2018. One dead in flooding as heavy rains hit Kuwait. Retrieved from http://www.arabnews.com/node/1402651/middle-east

Deckers, P., Kellens, W., Reyns, J., Vanneuville, W., De Maeyer, P., 2009. A GIS for flood risk management in Flanders. In Geospatial techniques in urban hazard and disaster analysis (pp. 51-69). Springer, Dordrecht.

Floodlist News in Asia, 2018. Middle East: Heavy rain and flooding in Iran, Iraq and Kuwait. Retrieved from http://floodlist.com/asia/flooding-iran-iraq-and-kuwaitnovember-2018

Gatchalian, R., Pandan, M. Tamayo, E., Villanueva, M., 2011. GIS in Flood Risks management: case Study of Cainta, Rizal. Retrieved on $3^{\text {rd }}$ May 2019 from https://eventhat.wordpress.com/2011/03/30/gis-in-floodrisk-management-a-case-study-in-cainta-rizal/.

Gharagozlou, A., Diarjan, M. H. Using GIS/RS for Flood Management (A case study in Golestan).

Isma'il, M., Saanyol, I. O., 2013. Application of remote sensing (RS) and geographic information systems (GIS) in flood vulnerability mapping: case study of River Kaduna. International Journal of Geomatics and Geosciences, 3(3), 618.

Liu, J. F., Li, J., Liu, J., Cao, R. Y., 2008. Integrated GIS/AHP-based flood risk assessment: a case study of Huaihe River Basin in China. Journal of natural disasters, 17(6), 110-114.

Musaoglu, N., Kaya, S., Seker, D. Z., Göksel, Ç., 2002. A case study of using remote sensing data and gis for land management; catalca region. In FIGXXII International congress Washington, DCUSA.

Sanyal, J., Lu, X. X., 2004. Application of remote sensing in flood management with special reference to monsoon Asia: a review. Natural Hazards, 33(2), 283-301.

Shanwad, U. K., Patil, V. C., Gowda, H. H., Shashidhar, K. C., 2012. Remote Sensing and GIS for Integrated Resource Management Policy-A Case Study in Medak Nala Watershed, Karnataka, India. American-Eurasian Journal of Agriculture \& Environmental Sciences, 12(6), 790-806.

The New Arab, 2018. Kuwait flood damages estimated at over $\$ 300 \quad$ million. Retrieved from https://www.alaraby.co.uk/english/news/2018/11/ 12/kuwait-flood-damages-estimated-at- over-300-million

Tran, P., Shaw, R., Chantry, G., Norton, J., 2009. GIS and local knowledge in disaster management: a case study of flood risk mapping in Viet Nam. Disasters, 33(1), 152-169. Uddin, K., Gurung, D. R., Giriraj, A., Shrestha, B,. 2013. Application of remote sensing and GIS for flood hazard management: a case study from Sindh Province, Pakistan. American Journal of Geographic Information System, 2(1), 1-5.
Vision International, 2019. Geoinformatics. Retrieved from http://www.visionkuwait.com/Geoinformatics/ 